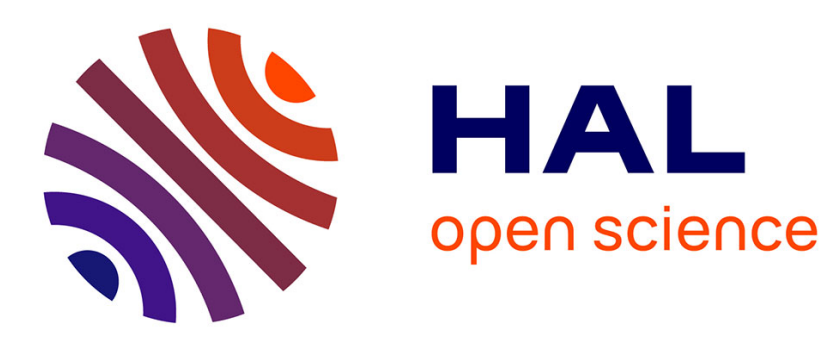

\title{
The biodiversity of dictyostelids in mountain forests: a case study in the French Alps
}

\author{
Yoan Paillet, M. Satre
}

\section{To cite this version:}

Yoan Paillet, M. Satre. The biodiversity of dictyostelids in mountain forests: a case study in the French Alps. Pedobiologia, 2010, 53 (5), pp.337 - 341. 10.1016/j.pedobi.2009.12.007 . hal-00496438

\section{HAL Id: hal-00496438 \\ https://hal.science/hal-00496438}

Submitted on 30 Jun 2010

HAL is a multi-disciplinary open access archive for the deposit and dissemination of scientific research documents, whether they are published or not. The documents may come from teaching and research institutions in France or abroad, or from public or private research centers.
L'archive ouverte pluridisciplinaire HAL, est destinée au dépôt et à la diffusion de documents scientifiques de niveau recherche, publiés ou non, émanant des établissements d'enseignement et de recherche français ou étrangers, des laboratoires publics ou privés. 
Author-produced version of the article published in : Pedobiologia, vol. $53, n^{\circ} 5$, p. $337-341$

The original publication is available at : http://www.sciencedirect.com/

doi : 10.1016/j.pedobi.2009.12.007

1 Title: The biodiversity of dictyostelids in mountain forests: a case study in the French

2 Alps

3

4 Authors: Yoan Paillet ${ }^{1,2^{*}}$, Michel Satre $^{3}$

$5 \quad{ }^{1}$ Cemagref, UR EMGR, 2 rue de la Papeterie BP 76, 38402 Saint-Martin-d'Hères, France

$6 \quad{ }^{2}$ Cemagref, UR EFNO, Domaine des Barres, 45290 Nogent-sur-Vernisson, France

7 'Univ Grenoble 1, CEA, CNRS, UMR 5092, Lab Biochim \& Biophys Syst Integres, iRTSV

8 BBSI, F-38041 Grenoble, France

$9 \quad{ }^{*}$ corresponding author Yoan.Paillet@cemagref.fr

10 


\section{Abstract:}

11 Forest management can seriously modify the biodiversity of forest dwelling species, but the consequences are poorly known for certain taxa, particularly soil fauna, for which few studies have been published. We compared the biodiversity of dictyostelids cellular slime moulds in

14 a managed and an unmanaged forest in the French Alps and analysed the influence of 15 environmental factors on species richness and abundance of dictyostelids. To our 16 knowledge, this study is the first one undertaken in the European Alps. We must better 17 understand the influence of various environmental factors on the biodiversity of these 18 organisms if we want to accurately define their functional role in the soil. In our study, 19 dictyostelids showed lower levels of diversity compared to previously published results. The mean species richness of dictyostelids was marginally higher in unmanaged than in

21 managed forests and biodiversity indices were significantly correlated with elevation and $\mathrm{pH}$.

22 This suggests that environmental factors have a predominant effect on the biodiversity of 23 dictyostelids and that the effect of forest management is secondary.

24 Keywords: Dictyostelids, forest management, mixed beech-fir-spruce stands, $\mathrm{pH}$, elevation. 
Introduction

26 The composition, structure and functions of European forests have been significantly 27 modified by centuries of human disturbance (Bengtsson et al., 2000). In turn, these modifications are thought to affect the biodiversity of forest dwelling species by changing forest site conditions such as topsoil and litter properties (Cassagne et al., 2006; Sebastia et al., 2005; Standovar et al., 2006). However, the real impact of forest management on species is still poorly understood. This is particularly true for soil communities, for which very few

32 studies have been published in Europe (Paillet et al., in press). This limited knowledge is 33 undoubtedly due to the difficulty of sampling soil fauna and to the fact that sampling protocols 34 often describe only a small part of soil total biodiversity (Fitter et al., 2005). Yet humaninduced changes in forest soil-dwelling communities are likely to deeply alter ecosystem functions (Scheu, 2005). In this context, unmanaged forests are a reference state both for biodiversity and for close-to-nature forest management.

38 Dictyostelids - cellular slime moulds - are a group of unicellular free living amoebae 39 particularly abundant in forest soils (Swanson et al., 1999). Within the soil trophic chain, 40 dictyostelids are of particular importance because they feed on soil bacteria, which helps to 41 control and modify soil bacteria populations (e.g. Feest, 1987). Dictyostelids also appear to stimulate the decomposition and mineralization of soil nutrients (Swanson et al., 1999). In this study, we compared dictyostelid communities in a managed and an unmanaged mixed beech-fir-spruce mountain forest with regard to forest characteristics. This study is the first carried out in the Alps. We hypothesized that species richness and abundance of dictyostelids would be higher in the unmanaged than in the managed forest and that environmental factors such as elevation and $\mathrm{pH}$ could have a significant effect on dictyostelid biodiversity.

Materials and methods

\section{Study site description}


The Massif du Vercors is a pre-alpine mountain range located in eastern France. The mountain range is calcareous, and is mainly characterized by high Urgonian cliffs and large scree deposits down the slopes. The vegetation has never been strongly influenced by human activity due to difficulty of access. While considerable deforestation has occurred elsewhere in the Alps, the Vercors has been quite well preserved.

Our study area is a forested natural reserve $\left(45^{\circ} 11^{\prime} 30^{\prime \prime} \mathrm{N}, 5^{\circ} 30^{\prime} 20^{\prime \prime} \mathrm{E}\right)$ that covers 920 ha. The climate is characterized by an average precipitation of more than $2000 \mathrm{~mm}$ per year at 1000 $\mathrm{m}$ a.s.I. and an annual mean temperature of $10^{\circ} \mathrm{C}$. The elevation of the montane range varies from 882 to 1636 m.a.s.I. The reserve area is comprised of a managed and an unmanaged part. The unmanaged zone has not seen any human disturbance for at least 10 years but had been extensively managed before.

\section{Sampling design}

We set up 5 study plots in both the managed and unmanaged parts. The plots were chosen on a $200 \times 200 \mathrm{~m}$ grid at random with respect to forest site homogeneity. However, as is often the case in the Alps, the unmanaged zones were at a slightly higher elevation than the managed zones. The main characteristics of the forest stands are summarized in Table 1.

On each study plot, three topsoil cores were sampled $10 \mathrm{~m}$ from the plot centre, in three directions (0,133 and 267 grads). A $25 \mathrm{~cm}^{3}$ soil core was sampled in the 5 first $\mathrm{cm}$ of topsoil, litter of the year removed. The three soil cores from each plot were mixed in a composite sample representative of the soil conditions of each plot. The soil properties of each composite sample were analysed by the INRA laboratory of Arras for the following properties: pH, Cation Exchange Capacity, organic carbon (C), mineral nitrogen (N). The ratio $\mathrm{C} / \mathrm{N}$ was calculated afterwards.

\section{Dictyostellid isolation}

A sub-sample of each composite sample was used to study dictyostelids. Isolation procedures used for dictyostelids followed Cavender and Raper (1965). Each sample was weighed and diluted for an initial soil/water ratio of 1:10. This mixture was shaken to disperse the material and to suspend the cells of the dictyostelids. A $5.0 \mathrm{~mL}$ volume of this initial 
dilution was added to $7.5 \mathrm{~mL}$ of sterile, distilled water to create a 1:25 dilution of sample material. Aliquots (each $0.5 \mathrm{~mL}$ ) of this suspension were added to each of two or three 95$100 \times 15 \mathrm{~mm}$ culture plates prepared with hay infusion agar (Raper, 1984) to produce a final dilution of $0.02 \mathrm{~g}$ of soil per plate. Approximately $0.4 \mathrm{~mL}$ of a heavy suspension of $E$. coli strain 281 was added to each culture plate, and plates were incubated under diffuse light at $20-25^{\circ} \mathrm{C}$. Each plate was examined at least once a day for several days after the appearance of initial aggregations. Dictyostelid species were then determined following Raper's nomenclature (1984).

\section{Statistical analyses}

We used Wilcoxon tests to compare differences in environmental and biodiversity data between managed and unmanaged forests. We used Spearman's rank correlation tests to assess the correlation between species richness and abundance of dictyostelids and environmental variables (elevation, soil and stand characteristics).

\section{Results}

Among environmental data, only spruce basal area differed significantly between managed and unmanaged forests $(P=0.03)$. Elevation $(P=0.06)$, dead wood volume $(P=0.1)$ and fir basal area $(P=0.1)$ only marginally differed between managed and unmanaged forests (Table 1).

Only five species of dictyostelids were found and noticeably, two plots were devoid of dictyostelid species (Table 2). Dictyostelid species richness tended to be higher in unmanaged than in managed plots $(P=0.09)$ whereas the number of clones was significantly higher in unmanaged plots $(P=0.05)$. Two species (Dictyostelium giganteum and Polysphondylium violaceum) appeared only in two plots. Conversely, Dictyostelium aureostipes and Dictyostelium mucuroides were the most frequent dictyostelid species and were more frequent in the unmanaged plots. Dictyostelium spaerocephalum was present both in managed and unmanaged forests but more frequent in the latter plots. 
107 We then sought environmental variables that correlated with dictyostelid biodiversity

108 indicators. We also looked for correlations between environmental variables (Table 3).

109 Species richness significantly correlated with elevation (Fig. 1), pH (Fig. 2) and Cation

110 Exchange Capacity (CEC) and marginally significantly with dead wood volume. Abundance

111 (clone number) significantly correlated with elevation and spruce basal area and marginally

112 with $\mathrm{pH}$ and deadwood volume. The highest Spearman's coefficient value occurred when

113 correlating species richness and elevation. Cation Exchange Capacity significantly correlated

114 with elevation and $\mathrm{pH}$. All the other correlations tested were non-significant.

\section{Discussion}

117 This exploratory study of dictyostelid biodiversity in managed and unmanaged forests is the

118 first to be set up in the Alps. Among the previous studies referenced in Swanson et al. 119 (1999), one did concern French forests but only in lowland areas (Cavender, 1969). Our 120 sampling design allowed us to isolate a relatively small number of dictyostelid species - only

121 five - compared to the 14 species isolated by Romeralo and Lado (2006) in Mediterranean

122 forests and to the 30 species isolated by Landolt et al. (2006) in the Great Smoky Mountains,

123 for example. Abundance was equally low, particularly in the managed plots which yielded 124 only an average of 16.40 clones per gram. These results may have been influenced by the relatively dry conditions during the sampling year (2007) but were most probably also due to the narrower and more controlled range of habitats we sampled. Indeed, previous studies had broader habitat types, e.g. ranging from bogs to subalpine forests in Landolt et al.

128 (2006). In addition, forest management in the reserve has been abandoned at least 10 years

129 before our study and recovery of soil biodiversity may be slow, as suggested by Paillet et al.

130 (in press) for other taxa. This slow recovery could thus be another explanation of the modest 131 values of biodiversity indices.

132 Dictyostelid species richness and abundance were higher in unmanaged than in managed 133 plots, thus suggesting the potential of unmanaged forests to host more dictyostelid species 134 than managed forests. Elevation and $\mathrm{pH}$ proved to be also correlated with biodiversity 
135 indices. Although our sampling protocol was relatively unbiased regarding elevation and $\mathrm{pH}$,

136 even the slight differences in elevation and $\mathrm{pH}$ seemed to explain the differences in species

137 richness and abundance. Indeed, several publications suggest that $\mathrm{pH}$ and elevation are

138 important drivers of dictyostelid species richness throughout the world (e.g. Swanson et al.,

139 1999). However, the positive relationships we found partly contradicted the literature: in our

140 study, the higher the elevation, the higher the biodiversity, whereas Landolt et al. (2006)

141 showed a negative effect of elevation on dictyostelid abundance and a positive effect on

142 species richness. Biodiversity indices also showed significant correlations with dead wood

143 volume and, for abundance only, basal area of spruce, which partly confirms the influence of

144 management on dictyostelid biodiversity.

145 In terms of species composition, the soils in the alpine forests we studied were more

146 comparable to those of boreal coniferous forests than to those of temperate deciduous

147 forests (Swanson et al., 1999). D. mucuroides is known to be a cosmopolitan species often

148 encountered throughout the world; indeed, this species was the more frequent in our

149 samples. Conversely, $P$. violaceum, another ubiquitous species, appeared only once in our

150 sample. $D$. sphaerocephalum is characteristic of boreal coniferous soils whereas the

151 relatively widespread $D$. aureo-stipes is more characteristic of deciduous temperate forests.

152 Surprisingly, this latter species, more characteristic of disturbed and cultivated soils

153 (Swanson et al., 1999), occurred more frequently in unmanaged than in managed plots. This

154 suggests differences in soil disturbance regime between managed and unmanaged forest

155 types. Finally, the single occurrence of $D$. giganteum was difficult to interpret.

156 In conclusion, elevation and $\mathrm{pH}$ have a predominant effect on the biodiversity of dictyostelids.

157 The effect of forest management is probably secondary but non negligible. Forest

158 management may have two opposite consequences on dictyostelid biodiversity. Firstly, soil

159 disturbance induced by wood harvesting may cause increased biodiversity levels as

160 suggested by Swanson et al. (1999). However, it is not certain that the soil disturbance

161 regime in managed forests is higher than in unmanaged forests where natural forest

162 dynamics, in particular treefalls and deadwood, may disturb physical and chemical soil 
163 properties as strongly as wood harvesting does in managed forests (Buckley et al., 2003;

164 Spielvogel et al., 2006). Secondly, different tree species composition in managed and 165 unmanaged forests may modify topsoil conditions, which then become unsuitable for 166 dictyostelids. In our case, the pH decrease caused by a higher proportion of Picea abies (e.g. 167 Augusto et al., 2003) may lead to a reduction in bacteria density, thus reducing food 168 availability for dictyostelids.

169 To assess the importance of soil protozoa in regulating soil ecosystem function (e.g. 170 Clarholm, 2005), we need to better understand the factors that influence dictyostelid 171 biodiversity. In particular, predator-prey relationships between bacterial and dictyostelids 172 communities have to be further explored with respect to environmental variables (Griffiths et 173 al., 1999), especially soil pH (Fierer and Jackson, 2006). Indeed, despite the low abundance 174 observed in this study, dictyostelids may structure bacterial communities on which they feed, 175 and play a role in important ecosystem processes such as nitrogen mineralisation (Clarholm, 176 2005). In this effort, unmanaged forests may be able to serve as a reference state to which

177 the effects of different management methods on biodiversity could be compared. This 178 comparison would also be a first step towards filling the gap of unknown biodiversity 179 differences between managed and unmanaged forests.

180

\section{Acknowledgements}

182 We are indebt to J. Grenet for collecting the soil samples and for field work during her

183 Master's degree training period (2007). We also thank M.-C. Joseph for helpful technical

184 assistance, F. Archaux and two anonymous reviewers for interesting comments on previous 185 drafts of this paper and V. Moore for polishing the language. This study was funded by the 186 "Conseil Général de l'Isère". 


\section{References cited}

192

193

194

195

196

197

198

199

200

201

202

203

204

205

206

207

208

209

210

211

212

213

214

215

216

217

218

219

220

221

222

223

224

225

226

227

228

229

230

231

232

233

234

235

236

237

238

239

240

Augusto, L., Dupouey, J.L. and Ranger, J., 2003. Effects of tree species on understory vegetation and environmental conditions in temperate forests. Ann. For. Sci. 60, 823831.

Bengtsson, J., Nilsson, S.G., Franc, A. and Menozzi, P., 2000. Biodiversity, disturbances, ecosystem function and management of European forests. For. Ecol. Manag. 132, 39-50.

Buckley, D.S., Crow, T.R., Nauertz, E.A. and Schulz, K.E., 2003. Influence of skid trails and haul roads on understory plant richness and composition in managed forest landscapes in Upper Michigan, USA. For. Ecol. Manag. 175, 509-520.

Cassagne, N., Gauquelin, T., Bal-Serin, M.C. and Gers, C., 2006. Endemic Collembola, privileged bioindicators of forest management. Pedobiologia 50, 127-134.

Cavender, J.C., 1969. The occurence and distribution of Acrasieae in forest soils. I. Europe. Am. J. Bot. 56, 989-992.

Cavender, J.C. and Raper, K., 1965. The Acrasiea in nature. I. Isolation. Am. J. Bot. 52, 294296.

Clarholm, M., 2005. Soil protozoa: an under-researched microbial group gaining momentum. Soil Biol. Biochem. 37, 811-817.

Feest, A., 1987. The quantitative ecology of soil Mycetozoa. In: D.J. Patterson and J.O. Corliss (Eds.), Progress in Protistology 2, pp. 331-361.

Fierer, N. and Jackson, R.B., 2006. The diversity and biogeography of soil bacterial communities. Proc. Natl. Acad. Sci. U. S. A. 103, 626-631.

Fitter, A.H. et al., 2005. Biodiversity and ecosystem function in soil. Funct. Ecol. 19, 369-377.

Griffiths, B.S., Bonkowski, M., Dobson, G. and Caul, S., 1999. Changes in soil microbial community structure in the presence of microbial-feeding nematodes and protozoa. Pedobiologia 43, 297-304.

Landolt, J.C., Stephenson, S.L. and Cavender, J.C., 2006. Distribution and ecology of dictyostelid cellular slime molds in Great Smoky Mountains National Park. Mycologia 98, 541-549.

Paillet, Y. et al., in press. Biodiversity differences between managed and unmanaged forests: meta-analysis of species richness in Europe. Conserv. Biol.

Raper, K., 1984. The dictyostelids. Princeton University Press, Princeton, New-Jersey.

Romeralo, M. and Lado, C., 2006. Dictyostelids from Mediterranean forests of the south of Europe. Mycol. Prog. 5, 231-241.

Scheu, S., 2005. Linkages between tree diversity, soil fauna and ecosystem processes. In: M. Scherer-Lorenzen, C. Körner and E.-D. Schulze (Eds.), Forest diversity and function: temperate and boreal ecosystems. Ecological studies. Springer-Verlag, Berlin, pp. 211-233.

Sebastia, M.T., Casals, P., Vojnikovic, S., Bogunic, F. and Beus, V., 2005. Plant diversity and soil properties in pristine and managed stands from Bosnian mixed forests. Forestry 78, 297-303.

Spielvogel, S., Prietzel, J. and Kogel-Knabner, I., 2006. Soil organic matter changes in a spruce ecosystem 25 years after disturbance. Soil Sci. Soc. Am. J. 70, 2130-2145.

Standovar, T., Odor, P., Aszalos, R. and Galhidy, L., 2006. Sensitivity of ground layer vegetation diversity descriptors in indicating forest naturalness. Community Ecol. 7, 199-209.

Swanson, A.R., Vadell, E.M. and Cavender, J.C., 1999. Global distribution of forest soil dictyostelids. J. Biogeogr. 26, 133-148. 
Table 1: Environmental, soil and stand characteristics in managed and unmanaged alpine forest plots. $\left({ }^{*}\right) \mathrm{P}<0.1,{ }^{*} \mathrm{P}<0.05$, n.s. non-significant result, SE : Standard Error.

\begin{tabular}{lccc}
\hline & Managed (n=5) & Unmanaged (n=5) & $\begin{array}{c}\text { Wilcoxon } \\
\text { test }\end{array}$ \\
\hline Environmental characteristics & & & \\
Elevation (m) (+/-SE) & $1098(67)$ & $1188(55)$ & $\left({ }^{*}\right)$ \\
Aspect & West & West & - \\
Soil characteristics & & & \\
pH (+/-SE) & $4.7(0.1)$ & $5.3(0.4)$ & n.s. \\
CEC (+/-SE) & $14.1(1.6)$ & $20.8(4.2)$ & n.s. \\
C/N (+/-SE) & $15.2(0.6)$ & $13.9(0.7)$ & n.s. \\
Stand characteristics & & & \\
Mean Basal Area (+/- SE) & $38.7(4.1)$ & $40.9(2.2)$ & \\
Mean Dead wood volume (+/- SE) & $20.1(11.8)$ & $85.5(37.6)$ & $\left({ }^{*}\right)$ \\
\%Basal Area Beech & 16.3 & 35.9 & n.s. \\
\%Basal Area Fir & 21.2 & 32.7 & $\left.{ }^{*}\right)$ \\
\%Basal Area Spruce & 53.1 & 15.4 & $*$ \\
\hline
\end{tabular}

243 Table 2: Dictyostelid relative abundance, species richness and abundance in managed and 244 unmanaged alpine forests

\begin{tabular}{|c|c|c|c|c|c|c|c|c|c|c|}
\hline \multirow{2}{*}{$\begin{array}{l}\text { Management } \\
\text { Plot }\end{array}$} & \multicolumn{5}{|c|}{ Managed plots $(n=5)$} & \multicolumn{5}{|c|}{ Unmanaged plots $(n=5)$} \\
\hline & 1 & 2 & 3 & 4 & 5 & 1 & 2 & 3 & 4 & 5 \\
\hline Dictyostelium aureo-stipes & $86 \%$ & & & & & $86 \%$ & $45 \%$ & $14 \%$ & $40 \%$ & $33 \%$ \\
\hline Dictyostelium giganteum & & & & & & & & & & $17 \%$ \\
\hline Dictyostelium mucuroides & $14 \%$ & $50 \%$ & $100 \%$ & & & $14 \%$ & $33 \%$ & $43 \%$ & $60 \%$ & $33 \%$ \\
\hline Dictyostelium sphaerocephalum & & $40 \%$ & & & & & $22 \%$ & $43 \%$ & & $17 \%$ \\
\hline Polysphondylium violaceum & & $10 \%$ & & & & & & & & \\
\hline $\begin{array}{l}\text { Mean species richness (+/-SE) } \\
\text { Mean abundance (clones g soil - } 1 \text { +/- } \\
\text { SE) }\end{array}$ & & & $1.20(0$. & & & & & $80(0.3$ & & \\
\hline
\end{tabular}

246 Table 3: Correlation matrix of Spearman's coefficients $(\rho)$ between dictyostelid biodiversity

247 indices and environmental variables. $\left({ }^{*}\right) P<0.1,{ }^{*} P<0.05$, n.s. non-significant result.

\begin{tabular}{|c|c|c|c|c|c|c|c|c|c|c|}
\hline & $\begin{array}{l}\text { Species } \\
\text { richness }\end{array}$ & Abundance & Elevation & $\mathrm{pH}$ & CEC & $\mathrm{C} / \mathrm{N}$ & $\begin{array}{c}\text { Basal } \\
\text { Area }\end{array}$ & $\begin{array}{c}\text { Dead } \\
\text { wood } \\
\text { volume }\end{array}$ & $\begin{array}{c}\text { Basal } \\
\text { Area } \\
\text { Beech }\end{array}$ & $\begin{array}{c}\text { Basal } \\
\text { Area } \\
\text { Fir }\end{array}$ \\
\hline Abundance & $0.840^{* *}$ & 1 & - & - & - & - & - & & - & - \\
\hline Elevation & $0.847^{* *}$ & $0.776^{\star *}$ & 1 & - & - & - & - & - & - & - \\
\hline $\mathrm{pH}$ & $0.804^{\star \star}$ & $0.585\left(^{*}\right)$ & n.s. & 1 & - & - & - & - & - & - \\
\hline CEC & $0.711^{*}$ & n.s. & $0.677^{*}$ & $0.721^{*}$ & 1 & - & - & - & - & - \\
\hline $\mathrm{C} / \mathrm{N}$ & n.s. & n.s. & n.s. & n.s. & n.s. & 1 & - & - & - & - \\
\hline Basal Area & n.s. & n.s. & n.s. & n.s. & n.s. & n.s. & 1 & - & - & - \\
\hline Dead wood volume & $0.573\left(^{*}\right)$ & $0.616\left(^{*}\right)$ & n.s. & n.s. & n.s. & n.s. & n.s. & 1 & - & - \\
\hline Basal Area Beech & n.s. & n.s. & n.s. & n.s. & n.s. & n.s. & n.s. & n.s. & 1 & - \\
\hline Basal Area Fir & n.s. & n.s. & n.s. & n.s. & n.s. & n.s. & n.s. & n.s. & n.s. & 1 \\
\hline Basal Area Spruce & n.s. & $-0.720^{*}$ & n.s. & n.s. & n.s. & n.s. & n.s. & n.s. & n.s. & n.s. \\
\hline
\end{tabular}


252 Figure 1: Relationship between dictyostelid species richness and elevation

253

254

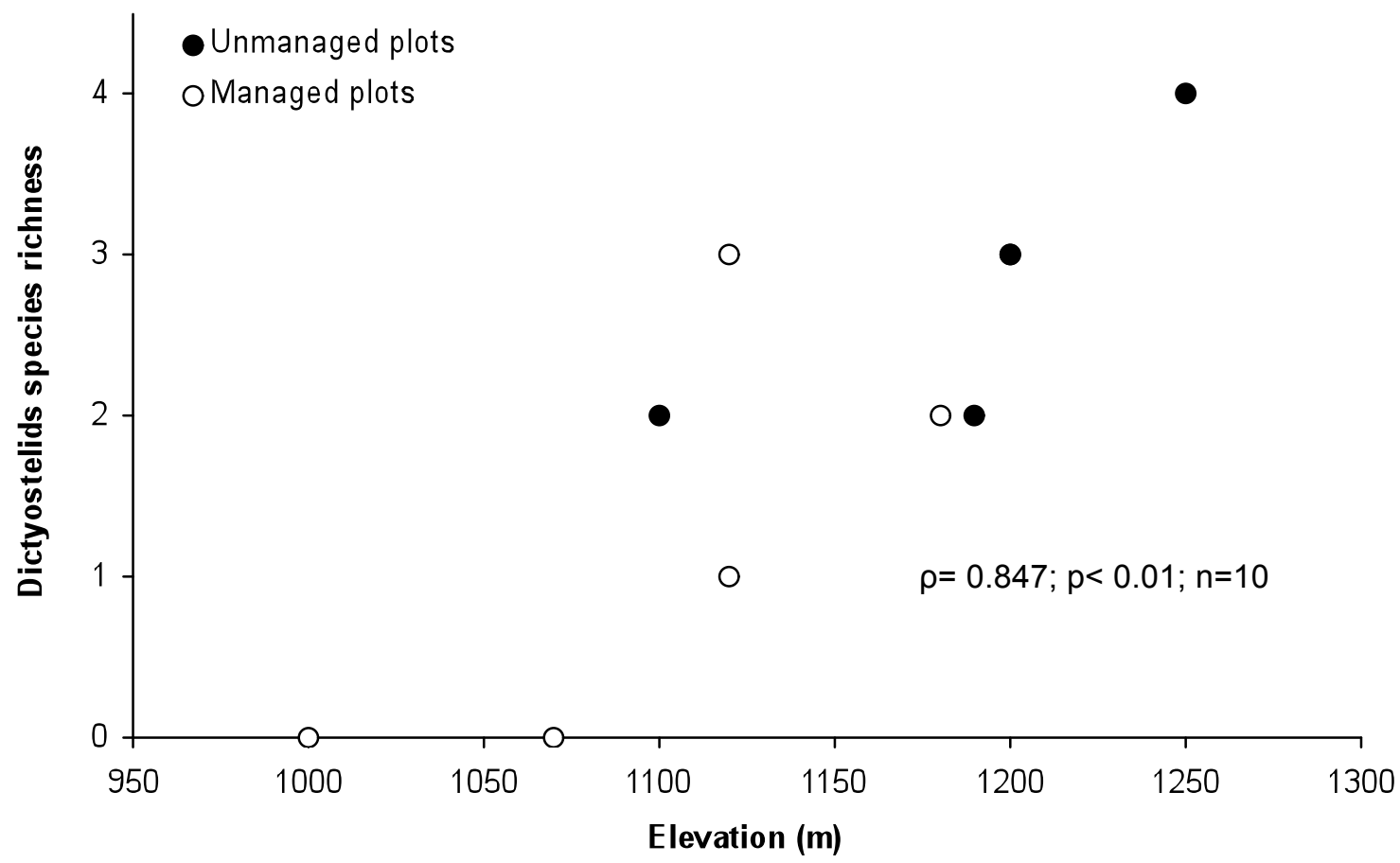

272

273

274

275

Figure 2: Relationship between dictyostelid species richness and $\mathrm{pH}$

276

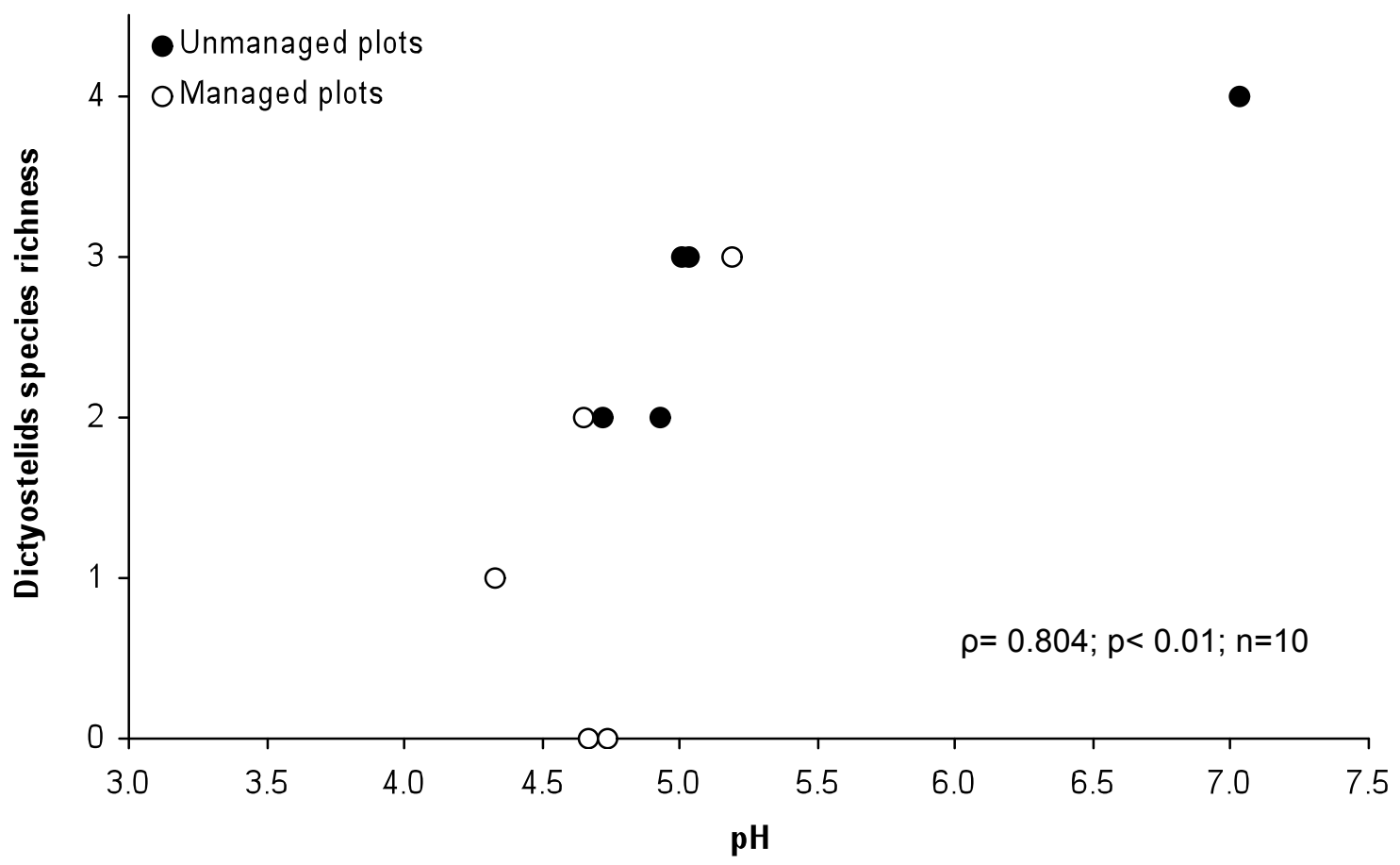

